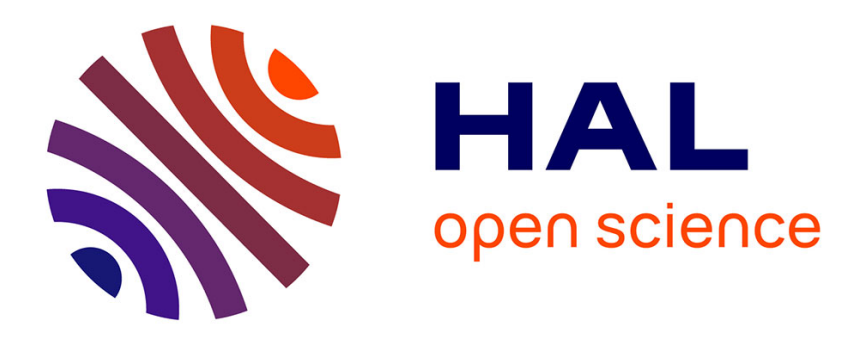

\title{
Microbiote et régulation du métabolisme énergétique
}

G. Mithieux

\section{To cite this version:}

G. Mithieux. Microbiote et régulation du métabolisme énergétique. Annales d'Endocrinologie, 2018, 79 (4), pp.193. 10.1016/j.ando.2018.06.007 . inserm-02393719

\section{HAL Id: inserm-02393719 https://www.hal.inserm.fr/inserm-02393719}

Submitted on 4 Dec 2019

HAL is a multi-disciplinary open access archive for the deposit and dissemination of scientific research documents, whether they are published or not. The documents may come from teaching and research institutions in France or abroad, or from public or private research centers.
L'archive ouverte pluridisciplinaire HAL, est destinée au dépôt et à la diffusion de documents scientifiques de niveau recherche, publiés ou non, émanant des établissements d'enseignement et de recherche français ou étrangers, des laboratoires publics ou privés. 
de l'exposé, ces recommandations seront présentées ainsi que les incertitudes actuelles en termes d'investigations préthérapeutiques, de traitement et de suivi.

Déclaration de liens d'intérêts L'auteur a déclaré les liens d'intérêts suivants Board : Ipsen, Novartis, Pfizer, AAA, Keocyt.

https://doi.org/10.1016/j.ando.2018.06.006

\section{II-05}

\section{Microbiote et régulation du métabolisme énergétique \\ Dr G. Mithieux \\ Inserm 1213, Lyon, France \\ Adresse e-mail : gilles.mithieux@inserm.fr}

Les fibres alimentaires (fermentées par le microbiote intestinal en acides gras à chaîne courte ou AGCC) que l'on trouve dans les fruits et légumes induisent des effets anti-obésité et anti-diabète, dont les mécanismes étaient mal compris. Des données récentes ont indiqué que la néoglucogenèse intestinale (NGI), une fonction promouvant des effets bénéfiques sur l'homéostasie énergétique à travers une signalisation centrale, joue un rôle clé dans les effets bénéfiques des fibres alimentaires. Nous avons montré que les AGCC propionate et butyrate, qui sont générés par la fermentation des fibres par le microbiote intestinal, activent la NGI par des mécanismes complémentaires. Le butyrate active localement l'expression des gènes de la NGI tandis que le propionate est substrat de la NGI et active l'expression de ses gènes par l'intermédiaire d'un circuit neuronal intestin-cerveau [1]. Plus récemment, nous avons montré que le précurseur du propionate dans le métabolisme bactérien, le succinate, est également un substrat de la NGI et contribue ainsi aux bénéfices des fibres [2]. Les bénéfices sur le poids corporel et le contrôle glycémique induits par les AGCC, le succinate, ou les fibres alimentaires chez la souris normale sont absents chez les souris déficientes pour la NGI, en dépit de modifications similaires de la composition du microbiote intestinal [1,2]. Ainsi, la régulation de la NGI par les AGCC et le succinate explique les avantages métaboliques associés aux fibres alimentaires.

Déclaration de liens d'intérêts L'auteur n'a pas précisé ses éventuels liens d'intérêts.
Further reading

[1] De Vadder F, et al. Cell 2014;156:84-96.

[2] De Vadder F, et al. Cell Metab 2016;24:151-7.

https://doi.org/10.1016/j.ando.2018.06.007

\section{II-06}

Role of gut peptide in diabetes remission after Roux-en-Y gastric bypass surgery

Pr B. Laferrère

Columbia university, New York, USA

E-mail address: bbl14@columbia.edu

Roux-en-Y gastric bypass surgery results in the resolution of type 2 diabetes in $\sim 60 \%$ of cases. Pre-surgery beta-cell function, with the large and sustained weight loss resulting from the surgery, are the main predictors of diabetes remission. However, enteric mechanisms, independent of weight loss, have been identified as important players. They include, among others, changes in intestinal metabolism, the gut hormones, the bile acids and the microbiome. The enhanced release of glucagon-like peptide 1 (GLP-1) contribute to the improvement of the incretin effect on insulin secretion during meals. GLP-1 and other gut peptides such as peptide YY and oxyntomodulin, may also contribute to the increased satiety and the decreased reward power of food observed after bypass, both contributing to decreased food intake and sustained weight loss. Although enteric factors are key for the full recovery of beta cell function during meals, the recovery of beta cell function in response to an IV glucose stimulus is more modest in magnitude, even in individual in diabetes remission. This may explain, in part, the long-term diabetes relapse in some patients. With the improvement of gut-mediated improved insulin secretion, RYGB results in large increase in insulin sensitivity and clearance, both contributors to improved glucose metabolism.

Disclosure of interest The author has not supplied his declaration of competing interest.

https://doi.org/10.1016/j.ando.2018.06.008 